NBER WORKING PAPER SERIES

\title{
U.S. WAGES IN GENERAL EQUILIBRIUM: THE EFFECTS OF PRICES, TECHNOLOGY, AND FACTOR SUPPLIES, 1963-1991
}

\author{
James Harrigan \\ Rita A. Balaban
}

Working Paper 6981

http://www.nber.org/papers/w6981

\section{NATIONAL BUREAU OF ECONOMIC RESEARCH 1050 Massachusetts Avenue \\ Cambridge, MA 02138 \\ February 1999}

We thank James Cassing for many helpful conversations, Sairah Burki for research assistance, and Susan Miller and Matthew Higgins for supplying some of the data. The paper has benefitted from comments by seminar participants at the NBER, Boston University, the University of Michigan, Michigan State, and MIT. The views expressed in this paper are those of the authors and do not necessarily reflect the position of the Federal Reserve Bank of New York, the Federal Reserve System, or the National Bureau of Economic Research. This paper is part of the NBER's research program in International Trade and Investment.

(0) 1999 by James Harrigan and Rita A. Balaban. All rights reserved. Short sections of text, not to exceed two paragraphs, may be quoted without explicit permission provided that full credit, including ${ }^{\circ}$ notice, is given to the source. 
U.S. Wages in General Equilibrium: The Effects

of Prices, Technology, and Factor Supplies, 1963-1991

James Harrigan and Rita A. Balaban

NBER Working Paper No. 6981

February 1999

JEL No. F1, J3, D5

\section{ABSTRACT}

Wage inequality in the United States has increased, and many suspect that the main causes are changes in technology, international competition, and factor supplies. Our empirical model estimates the general equilibrium relationship between wages and technology, prices, and factor supplies. The model is based on the neoclassical theory of production, and is implemented by assuming that GDP is a function of prices, technology levels, and supplies of capital and different types of labor. We find that relative factor supply and relative price changes are both important in explaining the growing return to skill. In particular, we find that capital accumulation and the fall in the price of traded goods served to increase the return to education.

James Harrigan

International Research Department

Federal Reserve Bank of New York

33 Liberty Street

New York, NY 10045

and NBER

james.harrigan@ny.frb.org
Rita A. Balaban

Department of Economics

University of Pittsburgh

and School of Business

Samford University

800 Lakeshore Drive

Birmingham, AL 35229 


\section{Introduction}

By most measures, the distribution of wealth and income in the United States has become more unequal in the past two decades. A primary cause of this increased inequality is increased wage inequality: the gap between what lesseducated and more-educated workers earn has grown steadily since about 1980 (see Figures 1 and 2). While these trends are well-established and of continuing interest to politicians, journalists, and ordinary people, economists have not reached a consensus on the causes of increased wage inequality. In the search for an answer, researchers have attributed the increase in wage inequality to changes in education, the decline of unions, immigration, and shifts in government spending, to name a few, but changes in technology, international trade, and relative factor supplies are considered by many to be among the most important potential explanations.

We take the view that the determination of economy-wide average wages is a general equilibrium phenomenon, where developments in one market for goods or factors influence equilibrium in other markets. Although general equilibrium theory is indispensable for understanding changes in wages, theory alone can not quantify the importance of the different determinants of wages, nor can it tell us even the signs of various effects except in simple models. We therefore develop a flexible empirical general equilibrium model, and apply it to data from 1963 to 1991. Our model uses the dual representation of a competitive economy's equilibrium to specify a system of equations that explain wages as a function of relative factor supplies, relative prices, and technological progress ${ }^{1}$. In the model,

\footnotetext{
${ }^{1}$ As far as we know, only Harrigan (1998) has followed a similar strategy to the one used in this paper. That paper is less closely linked to factor proportions trade theory than the current
} 
the effect of international trade on wages comes indirectly through trade's effect on relative prices. We find that changes in relative factor supplies and changes in relative prices both contributed to the increase in the relative wage of more skilled workers. The effect of international competition on relative prices is imprecisely estimated, so we are not able to shed much light on the influence of trade on wages.

\section{Theory}

Virtually all economists would agree that it is appropriate to model relative wages as being determined by the intersection of supply and demand curves for different types of labor. The analytical challenge comes in deciding how to specify supply and demand in a way that allows a decomposition of the causes of the observed changes in average wages. Such a model needs to be flexible enough that it doesn't rule out a priori any major possible influence on wages, and theoretically coherent enough that estimated parameters can be interpreted.

A quick look at the data suggests that relative labor supply changes can not by themselves explain the changes in relative wages: as skilled labor has become more abundant relative to less skilled labor, the relative wages of more skilled workers have risen (see, for example, Figures 2 and 4 below). Clearly this pattern is not consistent with labor supply shifts along fixed labor demand schedules, and this simple observation has led most economists to focus on demand changes as explaining the changes in relative wages ${ }^{2}$. Of course, changes in other factor

paper, and does not directly estimate the effect of sector-specific technical progress as we do here.

${ }^{2}$ Two recent theory papers, by Krugman (1998) and Acemoglu (1997), challenge this conventional wisdom. In Krugman's case, the model is explicitly intended to be treated as a thought experiment rather than as a serious candidate explanation for the rise in the return to 
supplies such as capital can also affect relative wages, and this channel is an important part of our empirical model.

Changes in the demand for labor can come about directly or indirectly. Direct changes in labor demand come from changes in technology or the prices of factors which substitute for a type of labor, such as capital or other types of labor. It is these channels that have been the main focus of labor and macro economists ${ }^{3}$. Indirect changes in labor demand come from changes in the demand for final products (arising, for example, from changes in the international economy) which use factors of production in different proportions. Changes in product demand will lead to changes in relative prices, and in multi-sector models these price changes can have dramatic effects on relative wages. This is the mechanism of the famous Stolper-Samuelson theorem of trade theory, and the importance of product price changes for relative wages has been studied by a number of economists ${ }^{4}$. Labor economists have also studied the effects of international trade on wages, but these efforts have been criticized for having a weak connection to theory and for treating trade as exogenous ${ }^{5}$. An argument about the right way to think about the effect of

education.

${ }^{3}$ See Berman, Machin and Bound (1997) for micro evidence from labor economists, and Krusell et. al. (1997) for a macroeconomic view.

${ }^{4}$ Lawrence and Slaughter (1993) were the first to look at the correlation of prices and wages. Other studies include Krugman and Lawrence(1993), Krueger (1997), Sachs and Shatz (1994), Leamer (1996a) and Baldwin and Cain (1997). A comprehensive review is given in Slaughter (1998).

${ }^{5}$ See, for example, Borjas, Freeman and Katz (1992), Murphy and Welch (1991), Katz and Murphy (1992), Berman, Bound, and Griliches (1994), Wood (1995) and the critique of these papers by Leamer (1994, 1996b). Deardorff and Hakura (1994) offer a particularly clear critique of the first wave of labor economists' studies of the effect of trade on wages. 
technological progress on relative wages has paralleled the controversy about how to model the effect of trade, with labor economists focusing on within-sector technological progress and trade economists stressing the importance of crosssector differences in the rate of technological progress ${ }^{6}$.

Several observations about these controversies are relevant to our motivation in writing this paper. Most fundamentally, since we are interested in explaining rather than describing the trends in wages, a well-specified model is required almost by definition. Second, since we are interested in explaining longterm trends in economy wide average wages, a multi-factor, multi-sector general equilibrium model is a natural choice as an analytical framework. General equilibrium theory teaches that the interactions between wages and changes in technology, international trade, and relative factor supplies are complex and difficult to analyze except in very special and low dimensional cases. For example, in the two good, two factor Heckscher-Ohlin-Samuelson (H-O-S) model, the Stolper-Samuelson Theorem states that an increase in the price of a good will lead to a more than proportional increase in the price of the factor used intensively in that good, and a fall in the price of the other factor. Also in the H-O-S model, factor supply changes have no direct impact on factor returns: holding prices fixed, factor supply changes change outputs, with the only possible factor price effects coming from any resulting changes in final goods prices (for reasons of intellectual history, this result has long been known as part of the factor price

\footnotetext{
${ }^{6}$ See Berman, Machin and Bound (1997) for a within-sector analysis of skill-biased technological change, and Krugman (1995) and Leamer (1994) for the argument that the skillbias of technological change is irrelevant.
} 
equalization theorem, but it has recently been more accurately re-named the "factor price insensitivity theorem" by Leamer (1995)).

These results are fragile in empirically relevant ways. For example, in models with more than two goods and factors, there is no simple connection between the factor intensities of sectors experiencing price changes and the resulting changes in factor prices. In addition, the factor price insensitivity theorem does not hold when there are more factors than goods, or if the changes in factor supplies are large enough that the set of produced goods can not be held fixed; in these cases, factor supply changes will have direct effects on factor prices as well as any indirect effects through resulting changes in final goods prices.

In the rest of this section we discuss the general equilibrium relationship between factor prices, factor supplies, and final goods prices in settings more general than the low-dimensional models used by the researchers mentioned above. Our exposition closely follows the standard treatments of Woodland (1982) and Dixit and Norman (1980). Consider a small open economy characterized by fixed aggregate factor supplies, constant returns to scale and competitive market clearing. As is well known, the general equilibrium of this economy will maximize the value of final output. A common formulation of this maximization problem is

Max $\mathbf{p} \cdot \mathbf{x}$ subject to $\mathbf{x} \in \mathrm{Y}(\mathbf{v})$ $\mathbf{p}, \mathbf{x} \in \mathbb{R}^{\mathrm{N}}, \mathbf{v} \in \mathbb{R}^{\mathrm{M}}$ where $\mathbf{x}$ is the final goods vector, $\mathbf{p}$ is the vector of final goods prices and $\mathrm{Y}(\mathbf{v})$ is the convex production set for endowments $\mathbf{v}$. The solution to this problem gives the maximized value of national income as $Y=r(\mathbf{p}, \mathbf{v})$. The dual function $r(\mathbf{p}, \mathbf{v})$ is known as the revenue or GDP function, and has properties which are analytically convenient. The vector of factor prices $\mathrm{w}(\mathbf{p}, \mathbf{v})$ is given by the (always unique) gradient of $\mathbf{r}(\mathbf{p}, \mathbf{v})$ with respect to $\mathbf{v}$ : 


$$
\mathrm{w}_{\mathrm{i}}(\mathbf{p}, \mathbf{v})=\partial \mathrm{r}(\mathbf{p}, \mathbf{v}) / \partial \mathrm{v}_{\mathrm{i}} \quad \mathrm{i}=1, \ldots, \mathrm{M}
$$

If in addition the revenue function $r(\mathbf{p}, \mathbf{v})$ is differentiable, then the vector of final outputs is given by the gradient of $r(\mathbf{p}, \mathbf{v})$ with respect to $\mathbf{p}$ :

$$
\mathrm{x}_{\mathrm{j}}(\mathbf{p}, \mathbf{v})=\partial \mathrm{r}(\mathbf{p}, \mathbf{v}) / \partial \mathrm{p}_{\mathrm{j}} \quad \mathrm{j}=1, \ldots, \mathrm{N}
$$

The inverse factor demand functions $\mathrm{w}_{\mathrm{i}}(\mathbf{p}, \mathbf{v})$ are homogeneous of degree one in $\mathbf{p}$ and zero in $\mathbf{v}$, and concave in $\mathbf{v}$. Concavity implies that factor prices are nonincreasing in factor quantities. The gradient of $\mathrm{w}_{\mathrm{i}}(\mathbf{p}, \mathbf{v})$ with respect to $\mathbf{p}$ is the vector of Stolper-Samuelson derivatives, that is, the general equilibrium effect of price changes on nominal wages. As noted above, in the case of two goods and two factors the Stolper-Samuelson and Factor Price Insensitivity theorems apply to these functions. With many goods and factors and no joint production, an increase in a product price will cause at least one factor price to increase and at least one factor price to decrease. However, an increase in the price of the most factor-i intensive good need not lead to an increase in $\mathrm{w}_{\mathrm{i}}$. With joint production, a price increase need not lead to a drop in any factor price. As for factor supply changes, small changes will not affect wages if there are at least as many goods as factors and if there is no joint production, but otherwise factor supply changes will affect factor prices ${ }^{7}$.

In our view, the theoretical fragility of the Stolper-Samuelson and Factor Price Insensitivity results makes them suspect as a way of organizing the study of an actual economy with many goods and factors. Since the general equilibrium

${ }^{7}$ As Kohli (1991, Chapter 4) points out, whether or not production is joint depends partly on what the level of aggregation is: a set of production functions might produce single outputs but an aggregate of the same production functions will produce joint outputs. See Jones and Scheinkman (1977) and Ethier (1984) for discussions of general equilibrium comparative statics when there are many goods and factors. 
effects of prices and factor supplies on wages are both practically important and theoretically uncertain, they need to be estimated empirically. This is the motivation for our data analysis.

Technological change will of course change the general equilibrium wage functions. We model technological change in a simple way, by assuming that there is Hicks-neutral technological change which occurs at different rates in different sectors. In addition to the standard assumptions on the revenue function, suppose that there exists a production function for each good given by

$$
\mathrm{x}_{\mathrm{j}}=\theta_{\mathrm{j}} \cdot \mathrm{f}^{\mathrm{j}}\left(\mathbf{v}^{\mathrm{j}}\right) \quad \mathrm{j}=1, \ldots, \mathrm{N}
$$

where $\theta_{\mathrm{j}}$ is a scalar parameter relative to a base period, and $\mathbf{v}^{\mathrm{j}} \in \mathbb{R}^{\mathrm{M}}$ is a vector of inputs. Increases in $\theta_{\mathrm{j}}$ represent Hicks-neutral technological progress in industry $\mathrm{j}$. It can be shown ${ }^{8}$ that the resulting revenue function has the form $r(\boldsymbol{\theta p}, \mathbf{v})$, where $\boldsymbol{\theta}$ $=\operatorname{diag}\left\{\theta_{1}, \theta_{2}, \ldots, \theta_{\mathrm{N}}\right\}$. This formulation makes it clear that industry specific neutral technological change has effects analogous to price increases, and factor prices are again given by the gradient of the revenue function with respect to $\mathbf{v}$, so that $\mathrm{w}_{\mathrm{i}}(\boldsymbol{\theta} \mathbf{p}, \mathbf{v})=\partial \mathrm{r}(\boldsymbol{\theta} \mathbf{p}, \mathbf{v}) / \partial \mathbf{v}_{\mathrm{i}}$. Finally, if there are other types of technological change which are not Hicks-neutral, we index them by time and write the revenue function as $Y=r(\theta p, v, t)$.

The assumption that product prices are fixed in response to factor supply and technology changes is only appropriate if all goods are traded and the country is too small to affect world prices. For a large economy with a large non-traded sector, such as the United States, prices will be endogenous, depending on factor

\footnotetext{
${ }^{8}$ See, for instance, Dixit and Norman (1980), pg. 137-139.
} 
supplies, technology, and other domestic and international influences on relative demand and supply ${ }^{9}$.

\section{An Empirical General Equilibrium Model of Wage Determination}

In this section we specify an econometric general equilibrium model of wage determination using the theory outlined in the previous section, with the goal of estimating the effects of technical progress, price changes, and factor supply growth on wages.

\subsection{Functional Form}

Following Kohli (1991) and Harrigan (1997), we assume that the economy's revenue function $r(\boldsymbol{\theta p}, \mathbf{v}, \mathrm{t})$ can be well approximated by a general translog function, which is simply a quadratic in $t$ and the $\operatorname{logs}$ of $\theta \mathbf{p}$ and $\mathbf{v}$ :

$$
\begin{aligned}
\ln r(\theta \boldsymbol{p}, \boldsymbol{v}, t)= & a_{o o}+\sum_{\mathrm{j}} a_{0 j} \ln \theta_{j t} p_{j t}+1 / 2 \cdot \sum_{\mathrm{j}} \sum_{\mathrm{k}} a_{j k} \ln \theta_{j t} p_{j t} \cdot \ln \theta_{k t} p_{k t} \\
& +\sum_{\mathrm{i}} b_{0 i} \ln v_{i t}+1 / 2 \cdot \sum_{\mathrm{i}} \sum_{\mathrm{m}} b_{i m} \ln v_{i t} \cdot \ln v_{m t} \\
& +\sum_{\mathrm{j}} \sum_{\mathrm{i}} c_{j i} \ln \theta_{j t} p_{j t} \cdot \ln v_{i t} \\
& +\mathrm{t} \cdot \sum_{\mathrm{j}} d_{0 j} \ln \theta_{j t} p_{j t}+\mathrm{t} \cdot \sum_{\mathrm{i}} d_{l i} \ln v_{i t}+d_{2} \cdot \mathrm{t}+d_{3} \cdot \mathrm{t}^{2}
\end{aligned}
$$

where the summations over $\mathrm{j}$ and $\mathrm{k}$ run from 1 to $\mathrm{N}$, and the summations over $\mathrm{i}$ and $\mathrm{m}$ run from 1 to $\mathrm{M}$. Symmetry of cross effects requires that $a_{j k}=a_{k j}$ and $b_{i m}=b_{m i}$ for all $\mathrm{j}, \mathrm{k}, \mathrm{i}$, and $\mathrm{m}$. Linear homogeneity in $\mathbf{v}$ and in $\mathbf{p}$ requires

$$
\begin{aligned}
& \sum_{\mathrm{j}} a_{0 j}=\sum_{\mathrm{i}} b_{0 i}=1 \\
& \sum_{\mathrm{j}} a_{j k}=\sum_{\mathrm{k}} a_{j k}=\sum_{\mathrm{i}} b_{i m}=\sum_{\mathrm{m}} b_{i m}=\sum_{\mathrm{i}} c_{j i}=\sum_{\mathrm{j}} c_{j i}=\sum_{\mathrm{j}} d_{0 j}=\sum_{\mathrm{i}} d_{l i}=0
\end{aligned}
$$

${ }^{9}$ If there are at least as many traded goods as non-traded goods plus factors, and no joint production, then traded goods prices uniquely determine both non-traded and factor prices. 
Differentiation of $\ln r(\theta p, v, t)$ with respect to $\ln v_{i}$ gives the share of factor $\mathrm{i}$ in GDP:

$$
S_{i t}=b_{0 i}+\sum_{m=2}^{M} b_{i m} \ln \frac{v_{m t}}{v_{1 t}}+\sum_{j=2}^{N} c_{j i} \ln \frac{\theta_{j t} p_{j t}}{\theta_{1 t} p_{1 t}}+d_{1 i} t
$$

where $\mathrm{S}_{\mathrm{it}}=\mathrm{w}_{\mathrm{it}} \cdot \mathrm{v}_{\mathrm{it}} / \mathrm{Y}_{\mathrm{t}}$ is the share of factor $\mathrm{i}$ in national income. Similarly, differentiation of $\ln r(\theta \boldsymbol{p}, \boldsymbol{v}, t)$ with respect to $\ln p_{j}$ gives the share of final output $\mathrm{j}$ in GDP:

$$
R_{j t}=a_{0 j}+\sum_{i=2}^{M} c_{j i} \ln \frac{v_{k t}}{v_{1 t}}+\sum_{k=2}^{N} a_{j k} \ln \frac{\theta_{k t} p_{k t}}{\theta_{1 t} p_{1 t}}+d_{0 j} t
$$

where $R_{j t}=p_{j t} \cdot x_{j t} / Y_{t}$ is the share of final output $j$ in national income ${ }^{10}$. In words, (1a) and (1b) state that the shares of factor $i$ and final output $j$ in national income are log-linear functions of relative factor supplies, technology levels, and prices. With time series data on factor prices, factor quantities, goods prices, sectoral technology levels, and valid instruments for any endogenous variables on the right hand side, the parameters of (1) can be econometrically estimated for all factors $i$ and sectors $\mathrm{j}$. The linear homogeneity conditions on the revenue function imply that there are M-1 linearly independent factor share and N-1 linearly independent output share equations to be estimated. Although we are primarily interested in the parameters of the factor share equations (1a), the fact that the $c_{j i}$ parameters appear in both (1a) and (1b) means that taking those cross-equation restrictions into account will result in more efficient estimates.

\footnotetext{
10 The linear homogeneity restrictions $\sum_{\mathrm{k}} a_{j k}=\sum_{\mathrm{m}} b_{i m}=\sum_{\mathrm{j}} c_{j i}=\sum_{\mathrm{i}} c_{j i}=0$ have been imposed on (1a) and (1b).
} 
The elasticities of nominal wages with respect to changes in factor supplies, prices, and technology levels are simple functions of the data and the parameters of equation (1). It is straightforward to show that the elasticity of $\mathrm{w}_{\mathrm{i}}$ with respect to an increase in the quantity of $\mathrm{v}_{\mathrm{i}}$ is

$$
\frac{\partial \ln w_{i t}}{\partial \ln v_{i t}}=\frac{b_{i i}}{S_{i t}}+S_{i t}-1
$$

Similarly, the elasticity of $\mathrm{w}_{\mathrm{i}}$ with respect to an increase in another factor supply, say $v_{k}$, is equal to

$$
\frac{\partial \ln w_{i t}}{\partial \ln v_{k t}}=\frac{b_{i k}}{S_{i t}}+S_{k t}
$$

Homogeneity implies that the sum of the own and cross quantity elasticities for factor i equals zero. The Stolper-Samuelson elasticities of nominal factor prices with respect to nominal goods prices are given by

$$
\frac{\partial \ln w_{i t}}{\partial \ln p_{j t}}=\frac{c_{j i}}{S_{i t}}+R_{j t}
$$

By homogeneity, the sum of these elasticities for each factor price equals one. Since the effects of Hicks-neutral technological change are similar to the effects of price changes in this model, it is not surprising that the elasticity of wages with respect to a Hicks-neutral technological change is the same as (4):

$$
\frac{\partial \ln w_{i t}}{\partial \ln \theta_{j t}}=\frac{c_{j i}}{S_{i t}}+R_{j t}
$$


Concavity of $r(\theta \mathbf{p}, \mathbf{v}, t)$ in $\mathbf{v}$ implies that the own-quantity inverse factor demand elasticities given by (2) are non-positive for all observations $t$. This amounts to an inequality restriction on the parameters $b_{i i}$ :

$$
b_{i i} \leq \operatorname{Min}_{\mathrm{t}}\left(1-\mathrm{S}_{\mathrm{it}}\right) \cdot \mathrm{S}_{\mathrm{it}} \quad \mathrm{i}=1, \ldots, \mathrm{M}
$$

Although we are not primarily interested in the output share equations (1b), convexity of $r(\boldsymbol{\theta} \mathbf{p}, \mathbf{v}, \mathrm{t})$ in $\mathbf{p}$ requires that output supply curves slope upwards, and since we will be jointly estimating equations (1a) and (1b) it is necessary to take this theoretical restriction into account. Simple algebra shows that convexity in $\mathbf{p}$ implies inequality constraints on the parameters $a_{j j}$ :

$$
a_{j j} \geq \operatorname{Max}_{\mathrm{t}}\left(1-\mathrm{R}_{\mathrm{jt}}\right) \cdot \mathrm{R}_{\mathrm{jt}} \quad \mathrm{j}=1, \ldots, \mathrm{N}
$$

To estimate the above model, we assume that actual factor shares deviate from equations (1) by a classical error term. We treat factor supplies as exogenous, and we use instrumental variables to control for the endogeneity of prices and current technology levels. This leads to a reduced form expression for the factor shares:

$$
S_{i t}=\beta_{0 i}+\sum_{m=1}^{M} \beta_{i m} \ln v_{m t}+\sum_{\ell=1}^{L} \beta_{i \ell} \ln z_{\ell t}+\beta_{i} \cdot t+\epsilon_{i t}
$$

where the $\beta$ 's are the reduced form coefficients, the $z_{\ell t}$ are the instruments for prices and technology, and $\mathrm{L} \geq 2 \mathrm{~N}$ is the number of instruments. The reduced form effect on wages of an increase in a factor supply is just

$$
\frac{\partial \ln w_{i t}}{\partial \ln v_{i t}}=\frac{\beta_{i i}}{S_{i t}}+S_{i t}-1
$$


when $\mathrm{i}=\mathrm{k}$, and

$$
\frac{\partial \ln w_{i t}}{\partial \ln v_{k t}}=\frac{\beta_{i k}}{S_{i t}}+S_{k t}
$$

otherwise. The reduced form elasticities given by (8) and (9) incorporate both the direct effect through the factor supply elasticities as well as the indirect effect through the effect of factor supplies on prices and technology. Finally, the elasticity with respect to one of the instruments is

$$
\frac{\partial \ln w_{i t}}{\partial \ln z_{\ell t}}=\frac{\beta_{i \ell}}{S_{i t}}
$$

The elasticities given by (10) are equal to the Stolper-Samuelson elasticities times the sum of the elasticities of prices and technology with respect to the instruments

$\mathbf{Z}$.

\subsection{Measurement and Data Construction}

We implement the above model using a four good, four factor breakdown of the US economy from 1963 to 1991. The starting point for our sample was dictated by the availability of wage data, and the endpoint was dictated by the availability of price and total factor productivity data. The four primary factors of production that we analyze are

1. High School dropouts - workers who did not complete High School.

2. High School graduates - workers who completed High School, but who did not complete a 4-year college degree.

3. College graduates - workers who have completed a 4-year college degree. 
4. Physical Capital - private, non-residential structures and equipment. Our four aggregate goods are

1. Non-traded goods intensive in less-skilled labor.

2. Non-traded goods intensive in skilled labor.

3. Traded goods intensive in less-skilled labor.

4. Traded goods intensive in skilled labor.

Here we discuss our aggregation scheme and data sources.

Data on wages and employment were gathered from the March Current Population Survey (CPS), 1964-1992. The CPS provides, amongst other variables, information on age, education, industry of employment, and both earned and unearned income. Details of the construction of our wage and weeks worked variables are contained in Appendix 1.

Our capital stock data is the real, net stock of private non-residential capital equipment and structures from the Bureau of Economic Analysis (BEA). We chose not to disaggregate capital because we have only limited degrees of freedom.

We classify economic activity into four sectors using two criteria: whether the sector is traded or non-traded, and whether the sector is more or less intensive in less-skilled workers than the economy as a whole. This classification was chosen based on three considerations. First, with a short time series it was necessary to have a small number of aggregates. Second, we wanted to group sectors with similar factor shares, since theory tells us that it is the relative factor intensity of sectors that influences the Stolper-Samuelson responses of factor prices to goods price changes. Finally, since we are interested in the potential effect of international trade on wages, we divide sectors into traded 
(manufacturing, mining, and agriculture) and non-traded (services) sectors. We used CPS data on the educational composition of the labor force by sector and BEA data on sectoral capital stocks to calculate the direct shares of each factor in sectoral value added. This data was combined with the 1977 input-output table to calculate the total (direct plus indirect) factor intensity of each input-output sector, since the total factor intensities are what matter for the Stolper-Samuelson effects. A sector is classified as skilled-labor intensive if the share of cost accounted for by workers with at least some college (13 or more years of education) is greater than the economy wide average. The composition of the aggregates is listed in Table 1.

Our measures of prices and technology are derived from a data set assembled over many years by a team of researchers headed by Dale Jorgenson and available from Jorgenson's web site ${ }^{11}$. A good introduction to Jorgenson's methodology is Jorgenson (1990). One of the hallmarks of Jorgenson's approach is an exceptionally careful and symmetrical treatment of all primary and intermediate inputs. On this view, a purchase of (for example) a new and better quality capital good raises total factor productivity (TFP) only insofar as the capital good's marginal product exceeds its rental price. As a result, in Jorgenson's accounting scheme most of what many researchers call an increase in TFP is credited to investment in physical or human capital. We use Jorgenson's data on sectoral inputs of quality adjusted capital, labor, energy, and materials to construct translog indices of TFP growth. We use these TFP indices to measure Hicks-neutral technological change. The calculation of TFP includes current sectoral factor shares as data, which introduces a potential simultaneity between the TFP indices

\footnotetext{
${ }^{11} \mathrm{http}: / /$ kuznets.harvard.edu/ djorgens
} 
and the aggregate factor shares. To control for this, we use lagged TFP as instruments for current TFP. Our sectoral price of value added data is also derived from Jorgenson's data set.

Because of the endogeneity of prices, we need instruments for prices which are plausibly correlated with prices and uncorrelated with the error term appended to equation (5). One of the major hypotheses to explain the increase in wage inequality is increased international competition from low wage countries. According to trade theory, such competition would affect U.S. workers indirectly, through the effect of foreign competition on the prices of goods produced by U.S. workers. This suggests variables reflecting foreign competition as good instruments for prices, and we selected instruments as follows. First, for each year in our sample we classified countries into quartiles based on their per capita GDP, as calculated from version 5.6 of the Penn-World Tables (see Summers and Heston 1991):

Poor - per-capita GDP less than 25\% of US per capita GDP. Low Income - per-capita GDP at least 25\% but less than 50\% of US per capita GDP.

Middle Income - per-capita GDP at least $50 \%$ but less than $75 \%$ of US per capita GDP.

Rich - per-capita GDP at least 75\% of US per capita GDP.

For each country, we computed what we think of as a measure of the presence of the country's labor supply in the international market: the labor supply multiplied by the ratio of gross trade to GDP, or "openness". This variable is intended to account for the fact that what may matter to U.S. workers is not the amount of low-wage labor in the world but the amount of that labor which is engaged in 
producing goods which are traded internationally. This labor supply variable was then summed across all countries in a particular relative income bracket to get the total effective labor supply by relative income quartile.

Of course, domestic prices will also depend on domestic variables which affect relative demand and supply. In addition to TFP and factor supplies, which enter equation (5), we also use the ratio of government purchases to potential GDP as an instrument for domestic prices. This is intended to capture relative demand shifts due to differences in the composition of public and private spending. Demographic changes may also affect relative demand, and we use summaries of the age structure developed by Fair and Dominguez (1991) and Higgins and Williamson (1997) to measure such effects. The two demographic variables are linear and quadratic functions of the share of the US population in different 5-year age brackets, as follows:

$$
\begin{aligned}
& \text { Age Structure } 1=\sum_{c=1}^{C} c \cdot \pi_{c} \\
& \text { Age Structure } 2=\sum_{c=1}^{C} c^{2} \cdot \pi_{c}
\end{aligned}
$$

where $\pi_{\mathrm{c}}$ is the share of the population in age cohort $\mathrm{c}$. 


\subsection{Data Preview}

Real wages from 1963 to 1995 are depicted in Figure 1. Wages for all three educational groups rose through the early 1970's, and stagnated for two decades; only in the mid-1990's did wages for all three types of workers rise again as they had consistently in the decade before 1973. As summarized in Table 2, the average real weekly wages of High School (HS) dropouts fell by 8\% during the 1970's and a further $15 \%$ during the 1990 's. The story for HS graduates was comparatively less grim, with a cumulative real wage loss of $10 \%$ between 1970 and 1990. In contrast, college graduates saw their real wages fall even faster than those of HS graduates during the 1970 's, and rise during the 1980's. The consequent movement in the college graduate/HS graduate relative wage is depicted in Figure 2: it fell during the 1970's and rose rapidly during the 1980 's, a trend that has continued into the mid-1990's.

Each type of labor's share of national income, the dependent variables in equations (1a), are shown in Figure $3^{12}$. The share of national income going to college graduates almost tripled, while the share going to HS dropouts fell from nearly a quarter to only $5 \%$ by 1995 . These trends are the product of the trends in wages and employment. As shown in Figure 4, the share of weeks worked by HS dropouts was over $40 \%$ in the early 1960 s, at a time when college graduates were less than $10 \%$ of the labor force. By 1995, HS dropouts were less than one-eighth, and college graduates more than a quarter, of the labor force. In raw numbers, weeks worked by HS dropouts fell by 30\% from 1970 to 1990, while weeks

\footnotetext{
${ }^{12}$ The labor shares discussed here are the shares of national income accruing to each type of labor in the form of labor compensation. We treat income accruing to capital separately even though some workers own shares of firms and hence also have capital income.
} 
worked by HS and college graduates nearly doubled and tripled respectively (see Table 2). Notably, the capital stock also nearly doubled over this period, implying large changes in the ratios of each type of worker to the capital stock.

Turning to our data on relative prices, Figure 5 shows the price of each of our four aggregates relative to a value-added weighted average of the other three prices $^{13}$. The long term trend in traded goods prices is negative, with skillintensive goods falling more steeply than unskill-intensive goods. The price of skill-intensive non-traded goods has risen dramatically, rising roughly $60 \%$ between 1960 and 1990. In contrast, the price of low-skill non-traded goods moved slowly, falling around $15 \%$ over 30 years.

A striking aspect of the price data visible in Figure 5 is the large swing in the price of low-skill traded goods: these rose dramatically in the 1970's, and abruptly fell during the early 1980's. This is mirrored by a sharp drop in the price of high-skill non-traded goods, which fell sharply during the 1970's and exploded during the 1980's. As noted in Table 1, Oil Refining is included in the low-skill traded sector, which naturally leads to the suspicion that the swings in these relative prices are driven by the well-known fluctuations in the price of oil. In fact, this is not the case: the correlation between the relative prices including and excluding oil is 0.97 .

${ }^{13}$ To clarify, consider the price index for non-traded unskilled goods. This price is divided by a chain-weighted geometric average of the prices of the other three goods, where the chainweights for period $t$ are equal to the arithmetic average of the period $t$ and $t-1$ shares of each of the three goods in GNP exclusive of non-traded unskilled goods. This ensures that the weights sum to one for each period and each aggregate. This weighting procedure is only used for the purposes of making Figure 5. In the regression analysis, the raw price indices are used, since the choice of numeraire is irrelevant. 
Table 3 analyzes the behavior of the price aggregates in greater detail. Looking at rows under the "Non-traded, Skilled labor intensive" heading, it becomes clear that changes in the price of skilled services largely account for the price swings between 1970 and 1990 seen in Figure 5. The two large sectors FIRE (Finance, Insurance, and Real Estate) and "Other" (a grab bag sector that includes health care, business services, entertainment, education, law, etc) had price declines of around $15 \%$ during the 1970's and price increases on the order of $40 \%$ during the 1980 's. Unfortunately, the data do not permit greater disaggregation of the service sectors. Excessive aggregation combined with the well-known problems of measuring real output in services suggest that these numbers should be interpreted with caution.

Turning to the data for "Traded, Unskilled labor intensive" sectors, the collapse in the price of textiles and apparel during the 1970's stands out. This is the relative price that Leamer (1996a) focuses on as an explanation for the rise in the skill premium during the 1980 's. While small sectors may be influential, it is worth noting that even in 1960 these two sectors accounted for only 1.7\% of GDP, a share which fell to $1 \%$ by 1980 . Finally, note the large drops in the prices of the skilled-labor intensive high tech tradeables, Electronics and Instruments, from 1970 to 1990 .

A potentially important explanation for relative price changes is differential growth in TFP by sector. If faster TFP growth in a sector is passed through into a proportional relative price decline, then there will be no impact on relative factor prices or sectoral resource allocation (to see this, note that it is the product of price and TFP, $\theta \mathbf{p}$, that enters the GDP function). In fact, the changes in relative prices are much larger than can be accounted for by differential TFP growth. This is 
apparent from Table 2, and can also be seen by comparing Figure 6 with Figure 5 . Figure 6 plots relative TFP levels on the same scale as the relative prices in Figure 5, and while it is apparent that differential TFP growth contributes to the relative price changes (for example, notice the drop in relative TFP in the skilled, nontraded sector during the 1980 's), the relative price changes are much bigger in absolute value.

Table 4 reports simple correlations between the factor shares and the explanatory variables of equation (1a). The table includes correlations in the raw data as well as correlations between variables after removal of linear trends. The factor shares are statistically well described by linear trends, as can be seen from the bottom row of the table. An inescapable conclusion is that, as in many such analyses, the trends are obscuring a large amount of information. This caveat should be kept in mind when reviewing the results described in the next section, where most of the parameters of interest are identified from the detrended data.

\subsection{Estimation Results}

Table 5 reports generalized method of moments estimates of equation (1a) for each of the three categories of labor. The parameters on log relative prices in the factor share equations also appear as parameters on log factor supplies in the output share equations, so for efficiency we estimate the factor share equations (1a) jointly with three output share equations (1b). In addition to homogeneity with respect to factor supplies and with respect to prices within each equation, there are three cross-equation equality restrictions which impose symmetry on the cross-factor supply effects, $b_{i m}=b_{m i}$. Finally, there are six cross-equation restrictions connecting the factor share and output share equations (each $c_{j i}$ parameter appears in two equations). In the first stage, relative prices are 
instrumented by all the exogenous variables plus the domestic and foreign instruments identified in the previous section.

The errors appended to equations (1a) are assumed to be serially uncorrelated. The presence of a linear trend in each equation makes serial correlation unlikely, but nevertheless we test this assumption against the alternative of AR1 errors using a Lagrange multiplier test as follows (see, for example, Davidson and MacKinnon (1993), section 10.10):

1. Estimate the model, and collect the residuals from each estimated equation.

2. For each equation, regress the residuals on their lag as well as all the exogenous and predetermined variables in the model, including instruments.

3. The t-statistic on the lagged residual is a valid test statistic for the null of no first order autocorrelation.

When this procedure is carried out for each equation separately, we can never reject the null. As pointed out by Berndt and Savin (1975), in a singular equation system such as the ones estimated in this paper, the autoregressive parameter must be the same in each equation. This suggests estimating all six residual regressions together by SURE and imposing the restriction that the autoregressive parameter is the same in each equation. Implementing this, we also fail to reject the null.

Concavity of $r(\boldsymbol{\theta} \mathbf{p}, \mathbf{v}, \mathbf{t})$ in $\mathbf{v}$ and convexity in $\mathbf{p}$ implies eight inequality constraints on the estimated share equations, as given by equations (6). The inequality constrained estimator solves a quadratic programming problem, and is implemented by sequential quadratic programming in the software package Gaussx. For the estimates in Table 5, two of these constraints are binding at some point in the data: the constraint on the own factor price elasticity for HS dropouts, 
and the constraint on the own output quantity elasticity for tradeable goods intensive in unskilled labor (the relevant parameter appears only in the output share equation and so is not reported in Table 5). The standard error on the own factor price elasticity for HS dropouts is therefore misleading, since the distribution is non-standard when the inequality constraint binds.

The estimates in Table 5 are not especially interesting on their own. Table 6 reports elasticities derived from Table 5 and the actual factor and output shares for 1980, using equations (2), (3), (4), and (5) ${ }^{14}$. The first observation to make about the factor quantity elasticities is that they are not zero - the Factor Price Insensitivity result does not hold for this dataset. All the own-factor quantity elasticities are non-positive, in each case equal to about -0.4. The cross-elasticities are thought provoking: for example, HS dropouts and HS graduates benefit from increases in the supply of each other (although the effect is not statistically significant), and both HS dropouts and HS graduates are hurt by increases in the supply of college graduates (in the latter case, significantly). The most striking cross-effect is the elasticity of wages with respect to capital accumulation: a ten percent increase in the capital stock has no measurable effect on HS dropout wages, it raises HS graduate wages by 6.2 percent, and it raises the wages of college graduates by nearly 10 percent. Since there is substantial capital accumulation over our sample period, these elasticities imply that capital accumulation is a major cause of increased wage inequality. More on this below.

${ }^{14}$ Since the elasticities are time-varying, there are as many calculated elasticities for each effect as there are years. We report 1980 because it is an intermediate year in our data set, but complete results are available upon request. The variances of the elasticities are computed by treating the factor shares as constants, so the standard errors of the elasticities are equal to the standard error on the relevant parameter from Table 5 divided by the level of the factor share. 
The elasticities of nominal wages with respect to prices, also known as the Stolper-Samuelson elasticities, are striking. For example, an increase in the price of non-traded skilled goods raises the wage of workers with the least and the most education, while hurting HS graduates. In contrast, an increase in the price of nontraded unskilled goods hurts HS dropouts while raising the nominal wages of HS and college graduates. The price effects of changes in traded goods prices are smaller and imprecisely estimated: about all that can be said is that an increase in the price of tradeable unskilled goods increases the wages of more educated workers ${ }^{15}$.

The next table presents a decomposition of actual wage changes during the 1970 's and 1980's into changes due to growth in factor supplies and prices. Using the estimated elasticities from Table 6 combined with the actual changes in prices, factor supplies, and TFP summarized in Table 2, Table 7 gives an answer to the question: what accounts for the change in wages during the 1970's and 1980's? The decomposition is constructed by multiplying the wage elasticity for 1980 with respect to each explanatory variable by the cumulative change in the explanatory variable. Turning first to the effects of changes in factor supplies, the effect of physical and human capital accumulation on increased wage dispersion is clear: as the row labeled "Capital" indicates, the effect of capital accumulation was to increase the wage of HS graduates relative to HS dropouts by $35 \%$, and to increase the college/HS dropout and college/HS graduate differentials by $64 \%$ and $21 \%$ respectively. However, as shown in the row labeled "College Graduates", the rapid

${ }^{15}$ The real wage effects of a Stolper-Samuelson elasticity between zero and one is ambiguous, since it depends on the consumption share of the good whose price has increased. 
growth in the share of the labor force with a college education roughly offset the effects of physical capital accumulation.

The fall in the number of HS dropouts acted to prop up their wages by $11 \%$, and to restrain the increase in the differential with HS and college graduates by $12 \%$ and $9 \%$ respectively. Surprisingly, growth in the number of HS graduates actually served to decrease wage inequality; this is because the estimated elasticity of college wages with respect to an increase in HS graduates is actually larger in absolute value than the own-elasticity for HS graduates.

The next six rows of Table 7 show the Stolper-Samuelson effects of changes in final goods prices on nominal, real, and relative wages. Overall, relative price changes served to increase wage inequality, especially with respect to the college/HS graduate differential: price changes led to real wage gains for HS dropouts and college graduates of $26 \%$ and $67 \%$ respectively, while they led to a large drop in HS graduate wages of almost $40 \%$. The largest single effect was the result of the big increase in the price of non-traded skilled services, which caused a sharp drop in HS graduate wages and large increases in HS dropout and college graduate wages.

The wage effects of technological progress were relatively small but important. Most notably, the net effect of differential TFP growth was to increase the wage of HS graduates relative to HS dropouts and college graduates. This is consistent with the conclusions of Haskell and Slaughter (1998).

The last two lines of Table 5 show how the model does overall. The biggest failure is that the model predicts a rise, rather than a fall, in the wages of HS dropouts. The magnitude of the predicted drop in the wages of more educated 
workers is larger than what actually occurred, but the model does pick up the sign of the rise in the college/HS graduate wage differential.

Tables 5, 6 and 7 report the direct effect of price, TFP, and factor supply changes but do not consider the indirect effects of changes in the exogenous variables through their effect on prices. The direct and indirect effects can be calculated from the reduced form regressions specified in equation (7). The 1980 elasticities derived from estimates of (7) are reported in Table $8{ }^{16}$. Unfortunately, the estimates are not very precise: of the 45 elasticities reported, only 17 are statistically significantly different from zero using a $10 \%$ standard normal critical value of 1.64. As a result, it is not possible to say with confidence what the total direct and indirect effects of, for example, TFP changes are. It is also not possible to say how international competition affected wages, although the international factors are jointly significant in each reduced form regression ${ }^{17}$. These poor results are doubtless due to the substantial multicollinearity among the explanatory variables. The contrast between the fairly precisely estimated structural form elasticities of Table 3 and the imprecise estimates of the reduced form elasticities of Table 6 can be explained by noting that the effect of relative prices on wages is relatively well estimated while the processes determining relative prices are not well understood. Econometrically, this is largely due to the large number of restrictions that theory places on the system of structural equations, while no theoretical restrictions are imposed on the price equations.

16 The regression estimates are available upon request.

${ }^{17}$ The relevant F-statistics exceed the 5\% critical value in each case. Detailed results are available upon request. 
Despite the overall poor results in Table 8, there are some interesting estimates. For example, capital accumulation raised the wages of all workers, but benefitted college graduates disproportionately. In contrast, government purchases lowered the wages of less educated workers and had no discernible effect on the wage of college graduates. TFP growth seems to have had negligible effects on wages. Turning to the effect of foreign competition on wages, the point estimates are that increased effective foreign labor supply from low and middle income countries increased wage inequality. This inference is very provisional given the large standard errors and small elasticities, however ${ }^{18}$.

Although we can not say with confidence why relative prices changed, it is worth reiterating our finding that the fall in the relative price of traded goods (see Table 2 and Figure 5) had a large positive effect on the college/HS graduate relative wage (Table 7). This pattern is consistent with an explanation of relative wage movements which stresses the effects of a fall in the price of traded goods because of increased international competition.

Finally, intellectual honesty compels us to reiterate that these results are heavily dependent on untestable theoretical and statistical restrictions. On the theory side, we have imposed a fairly unrestricted general equilibrium model, which is then approximated by a flexible functional form. Theory also guided our choice of instrumental variables. This represents an advance on most of the earlier work on this topic, which either does not use general equilibrium analysis at all or uses it in a very restrictive way. Statistically, the primary limitation of the data analysis, both here and elsewhere, is that the relevant time series are short and

18 In a related paper which directly estimates the effects of import prices on factor prices, Harrigan (1998) found that trade had at most a small effect on wages. 
have strong trends. We have showed that our conclusions - that movements in both factor supplies and relative prices help explain changes in relative wages - are consistent with the data, but we make no claim to definitively rule out alternative, or supplementary, hypotheses.

\section{Conclusion}

This paper has estimated an econometric general equilibrium model of United States wages as a function of prices, technology, and factor supplies. The model comes from an application of a flexible functional form to the dual representation of a neoclassical economy's equilibrium. Factor supplies are taken as exogenous, and domestic and foreign instruments are used to control for the endogeneity of prices and current TFP.

The results are striking: both relative price changes and capital accumulation worked to increase the relative wage of college educated workers. The size of the estimated factor supply effects indicates that the Factor Price Insensitivity theorem, which predicts that factor prices should not change when factor supplies change, is not applicable to this data set. The large size of the capital stock elasticities is consistent with the widespread view (for example, Berman, Machin, and Bound (1997) and Krusell et. al. (1997)) that technological change embodied in new capital goods has contributed to an increase the return to education. 


\section{References}

Acemoglu, Daron, 1997, "Why Do New Technologies Complement Skills?

Directed Technical Change and Wage Inequality", CEPR Discussion Paper no. 1707 (October).

Baldwin, Robert E., and Glen Cain, 1997, "Shifts in U.S. Relative Wages: The Role of Trade, Technology, and Factor Endowments", NBER Working Paper no. 5934 (February).

Berman, Eli, John Bound, and Zvi Griliches, 1994, "Changes in the Demand for Skilled Labor Within US Manufacturing Industries: Evidence from the Annual Survey of Manufactures", Quarterly Journal of Economics, v. 109 no. 2: pp. 367-397.

Berman, Eli, Stephen Machin, and John Bound, 1997, "Implications of Skill Biased Technological Change: International Evidence", NBER Working Paper No. 6166.

Berndt, E.R. and N.E. Savin, 1975, "Estimation and hypothesis testing in singular equation systems with autoregressive disturbances", Econometrica 43, 93757.

Borjas, George J., Richard B. Freeman, and Lawrence F. Katz, 1992, "On the Labor Market Effects of Immigration and Trade", in Borjas, George J., and Richard B. Freeman, Eds., 1992, Immigration and the Work Force: Economic Consequences for the United States and Source Areas, Chicago: University of Chicago Press.

Davidson, Russell and James G. MacKinnon, 1993, Estimation and inference in econometrics, Oxford: Oxford University Press. 
Deardorff, Alan V., and Dalia S. Hakura, 1994, "Trade and Wages: What are the Questions?", in Bhagwati, Jagdish, and Marvin H. Kosters, Eds., 1994, Trade and Wages: Leveling Wages Down?, Washington, DC: AEI Press. Dixit, Avinash, and Victor Norman, 1980, The Theory of International Trade, Cambridge, England: Cambridge University Press.

Ethier, Wilfred, 1984, "Higher Dimensional Issues in Trade Theory", Chapter 3 in Ronald Jones and Peter Kenen, Eds, The Handbook of International Economics: Volume 1, International Trade, Amsterdam: North Holland. Fair, Ray, and Kathryn Dominguez, 1991, "Effects of the Changing U.S. Age Distribution on Macroeconomic Equations", The American Economic Review v. 81 \#5 (December): 1276-1294.

Harrigan, James, 1997, "Technology, Factor Supplies and International Specialization: Estimating the Neoclassical Model", The American Economic Review, v. 87 no. 4 (September): 475-494.

Harrigan, James, 1998, "International Trade and American Wages in General Equilibrium, 1967-1995", NBER Working Paper No. 6609 (June) and Federal Reserve Bank of New York Staff Report no. 46 (September). Haskel, Jonathan E. and Matthew J. Slaughter, 1998, "Does the Sector Bias of Skill-biased Technical Change Explain Changing Wage Inequality ?", NBER Working Paper no. 6565, May.

Higgins, Matthew, and Jeffrey G. Williamson, 1997, "Age Structure Dynamics in Asia and Dependence on Foreign Capital", Population and Development Review 23(2): 261-93. 
Jones, Ronald and Jose Scheinkman, 1977, "The Relevance of the Two-Sector Production Model in Trade Theory", Journal of Political Economy, v. 85, \#5: 909-935.

Jorgenson, Dale W., 1990, "Productivity and Economic Growth", Chapter 3 in Ernst R. Berndt and Jack E. Triplett, Eds, Fifty Years of Economic Measurement: The Jubilee of the Conference on Research in Income and Wealth, Volume 54 of NBER Studies in Income and Wealth, Chicago: University of Chicago Press.

Katz, Lawrence F., and Kevin Murphy, 1992, "Changes in Relative Wages in the United States, 1963-1987: Supply and Demand Factors", Quarterly Journal of Economics, v. 107 no. 1 (February): pp. 35-78.

Kohli, Ulrich, 1991, Technology, Duality, and Foreign Trade, Ann Arbor:

University of Michigan Press.

Krueger, Alan, 1997, "Labor Market Shifts and the Price Puzzle Revisited", NBER Working Paper no. 5924.

Krugman, Paul, 1995, "Technology, Trade, and Factor Prices", NBER Working Paper no.5355, November.

Krugman, Paul, 1998, "And now for something completely different", mimeo, March.

Krugman, Paul, and Robert Lawrence, 1993, “Trade, Jobs, and Wages”, NBER Working Paper no. 4478, September.

Krusell, Per, Lee Ohanian, José-Victor Ríos-Rull, and Giovanni Violante (1997) "Capital-Skill Complementarity and Inequality", Federal Reserve Bank of Minneapolis Research Department Staff Report no. 239. 
Lawrence, Robert Z., and Matthew J. Slaughter, 1993, "International Trade and American Wages in the 1980s: Giant Sucking Sound or Small Hiccup?”, Brookings Papers on Economic Activity, Microeconomics, pp. 161-210.

Leamer, Edward E., 1994, “Trade, Wages and Revolving Door Ideas”, NBER Working Paper no. 4716, April.

Leamer, Edward E., 1995, "The Heckscher-Ohlin Model in Theory and Practice", Princeton Studies in International Finance no. 77.

Leamer, Edward E., 1996a, "In Search of Stolper-Samuelson Effects on U.S. Wages”, NBER Working Paper no. 5427, January.

Leamer, Edward E., 1996b, "What's the Use of Factor Contents?”, NBER Working Paper no. 5448, February.

Murphy, Kevin M., and Finis Welch, 1991, "The Role of International Trade in Wage Differentials", in Marvin H., Editor, 1991, Workers and Their Wages:

Changing Patterns in the United States, Washington, DC: AEI Press.

Murphy, Kevin M., and Finis Welch, 1992, "The Structure of Wages", Quarterly Journal of Economics v. 107 no. 1 (February): 285-326.

Park, Jin-Heum, 1996, "Measuring Education over Time: A Comparison of Old and New Measures of Education from the Current Population Survey," Economic Letters v. 50 no. 3 (March): 425-428.

Sachs, Jeffrey D., and Howard J. Shatz, 1994, "Trade and Jobs in U.S. Manufacturing”, Brookings Papers on Economic Activity 1: pp. 1-84. Slaughter, Matthew J., 1998, "What are the Results of Product-Price Studies, and What Can We Learn From Their Differences?", NBER Working Paper no. 6591, June. 
Summers, Robert, and Alan Heston, 1991, "The Penn World Table (Mark V): An Expanded Set of International Comparisons, 1950-1988" Quarterly Journal of Economics, v. 106: 327-368.

Wood, Adrian, 1995, "How Trade Hurt Unskilled Workers", Journal of Economic Perspectives, v. 9 no. 3, Summer, pp. 57-80.

Woodland, Alan. D., 1982, International Trade and Resource Allocation, Amsterdam: North Holland. 

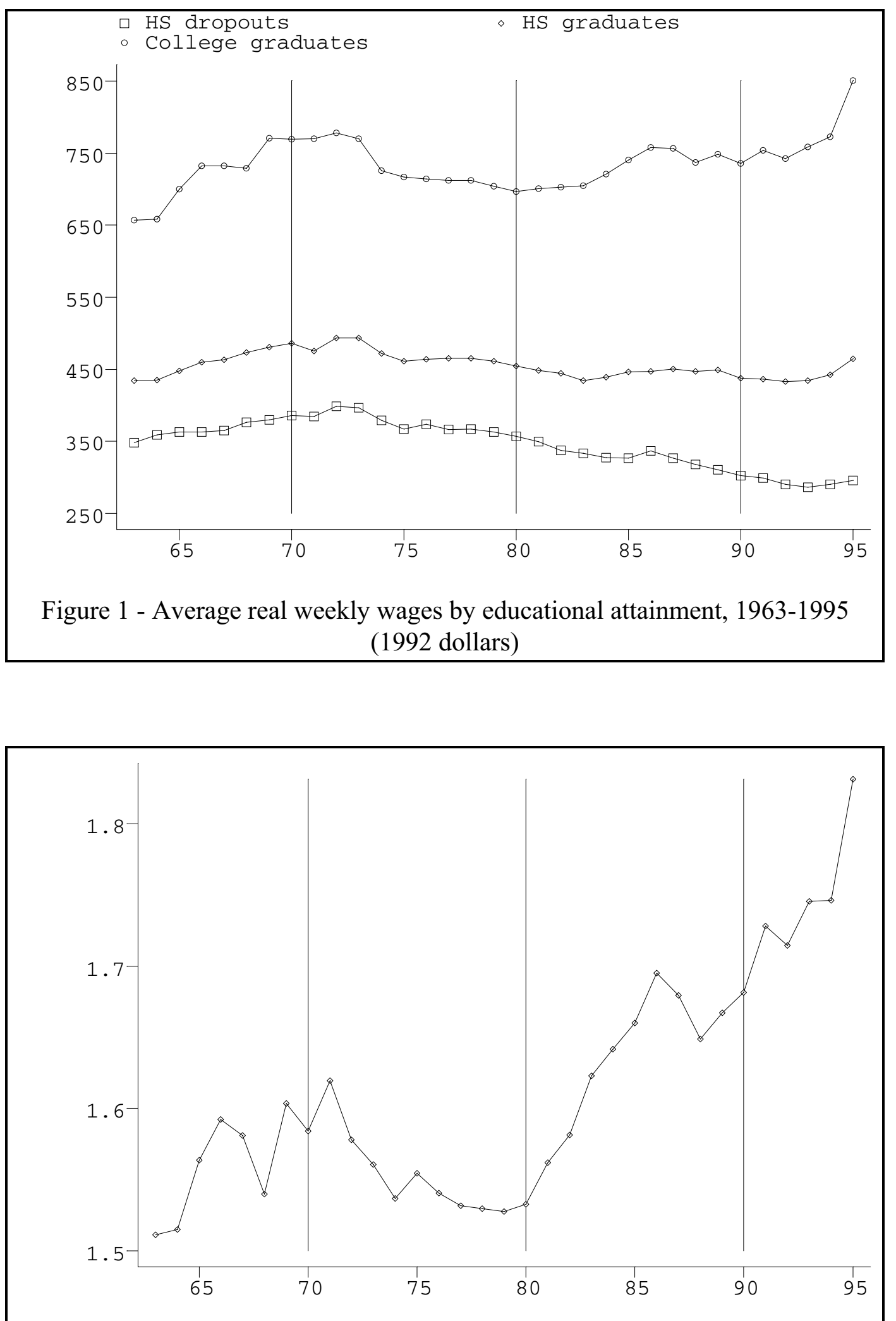

Figure 2 - College graduate/HS graduate relative average weekly wage, 1963-1995 


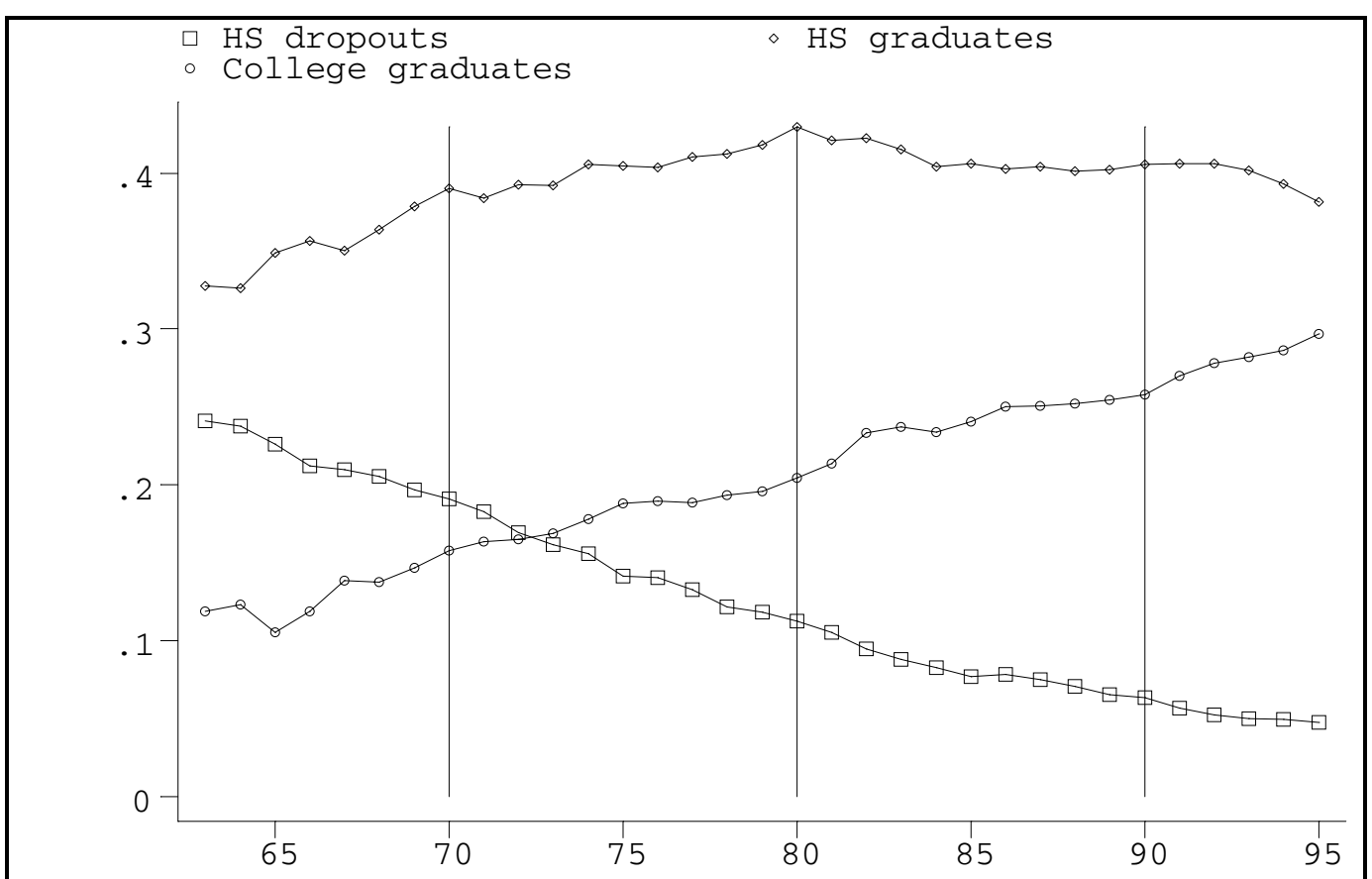

Figure 3 - Labor's share of national income by educational attainment, 1963-1995

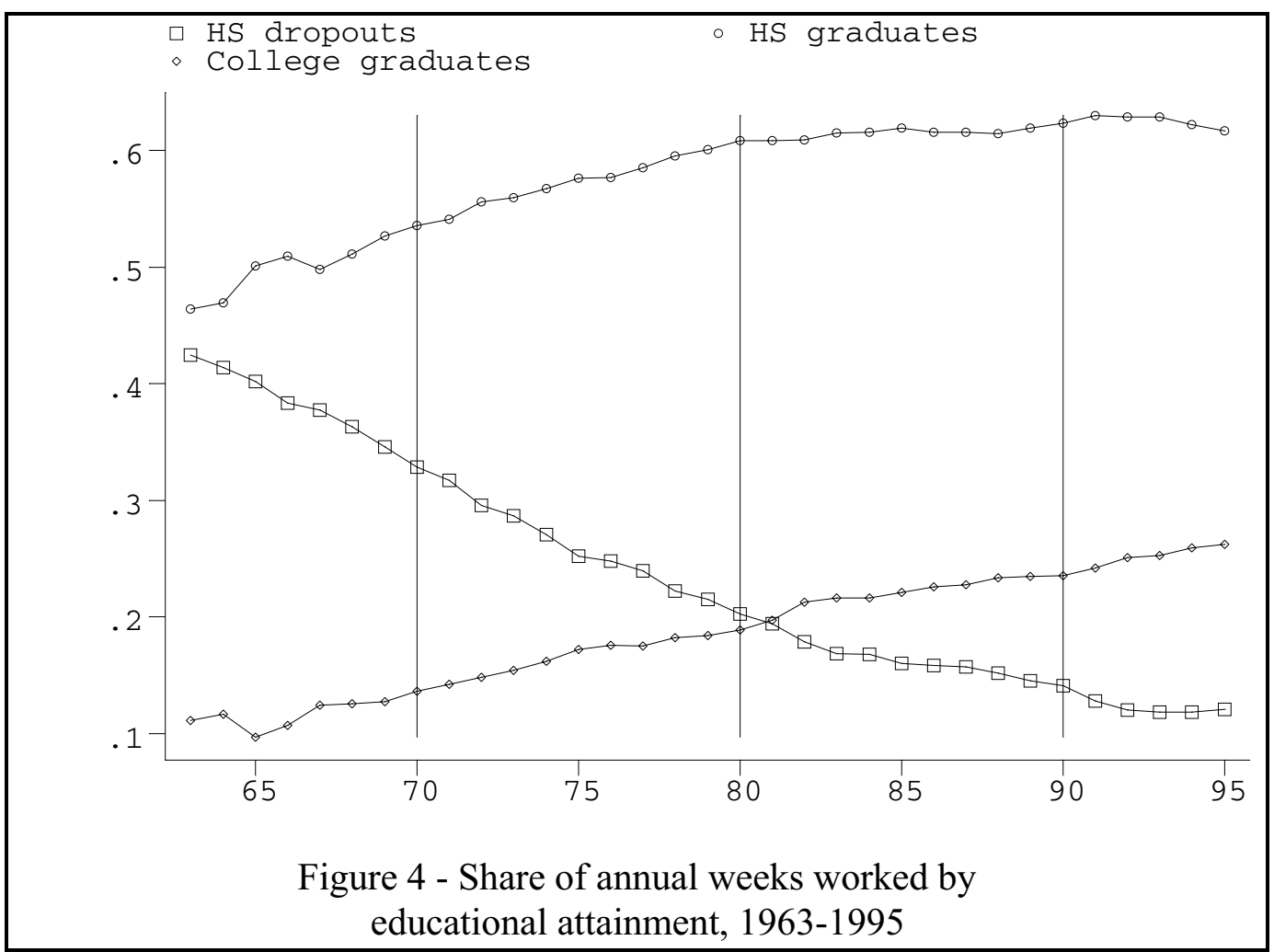




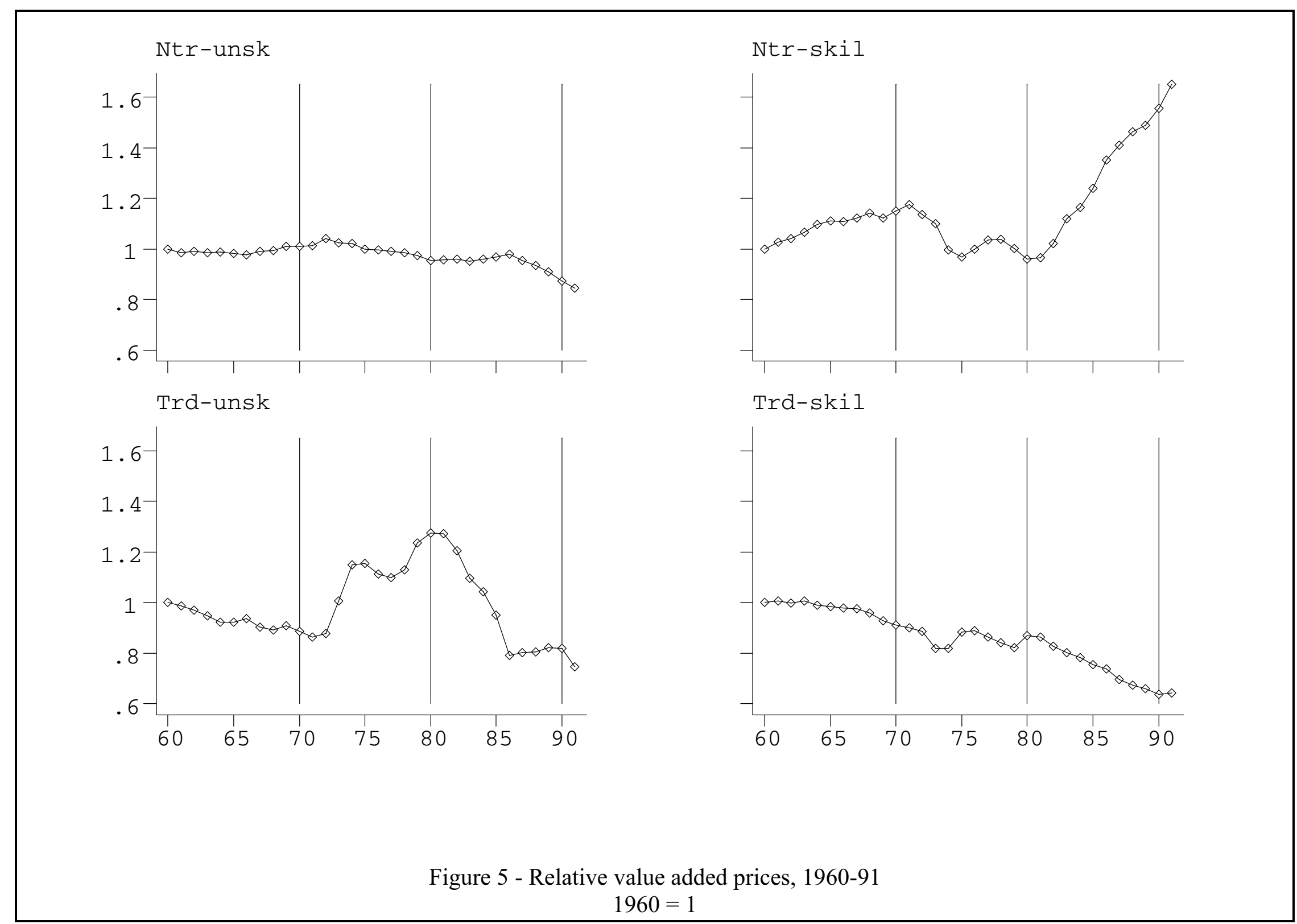




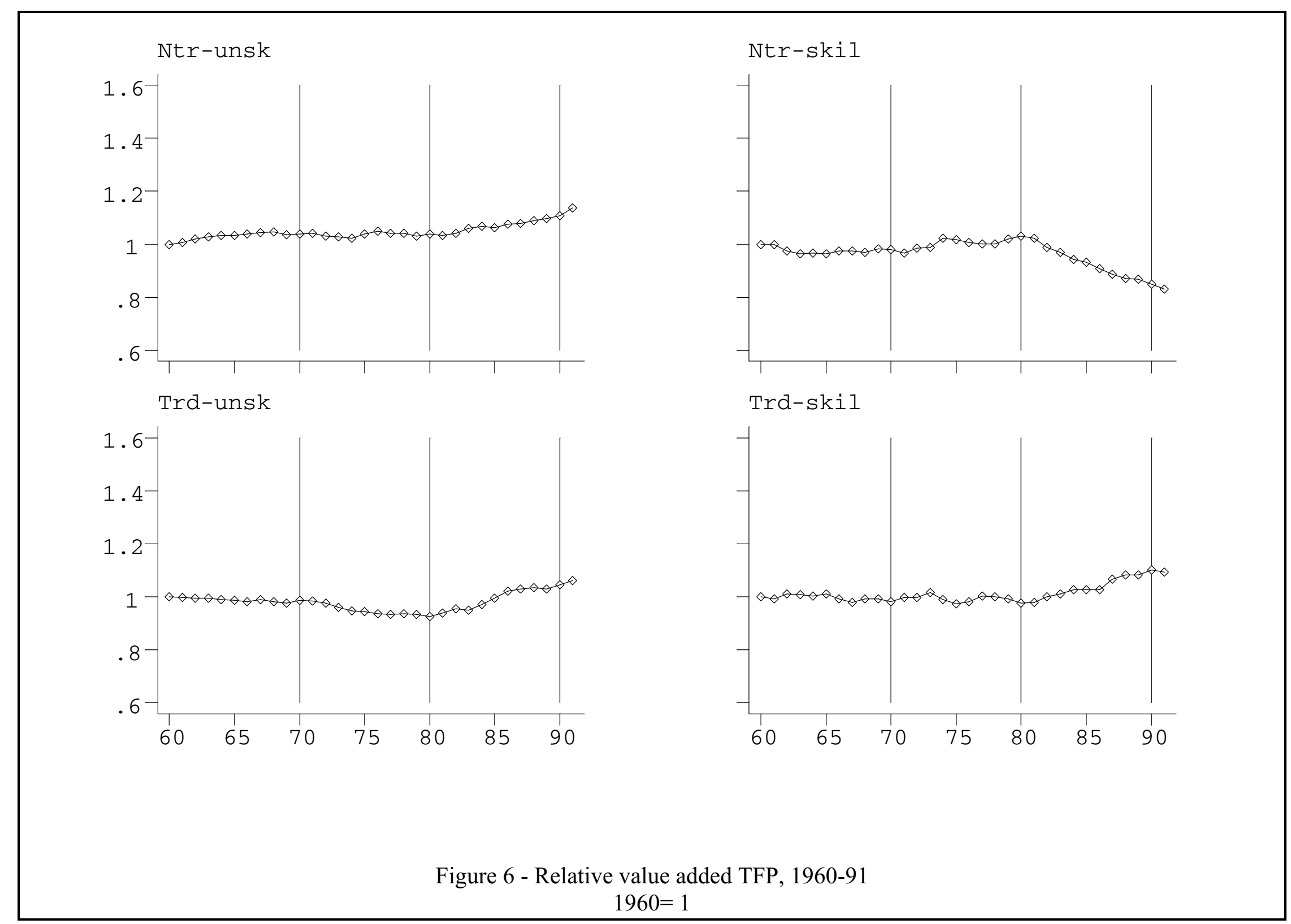




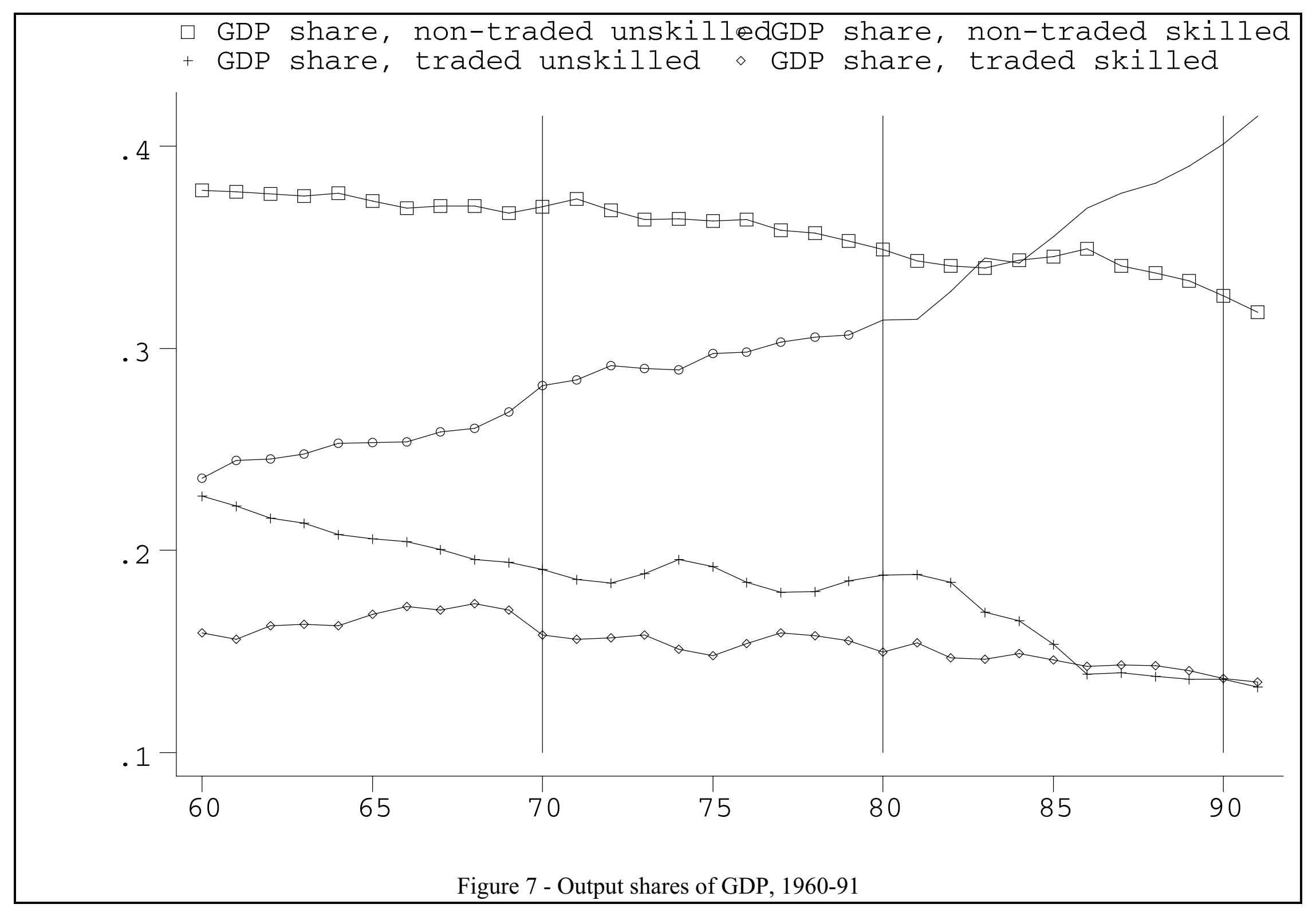


Table 1 - Composition of Output Aggregates

Aggregate Sector

\begin{tabular}{|c|c|}
\hline Non-Traded, Unskilled labor intensive & $\begin{array}{l}\text { Public Utilities } \\
\text { Transportation } \\
\text { Construction } \\
\text { Communications } \\
\text { Wholesale and Retail Trade }\end{array}$ \\
\hline Non-Traded, Skilled labor intensive & $\begin{array}{l}\text { Government } \\
\text { Finance, Insurance, and Real Estate (FIRE) } \\
\text { Miscellaneous other services (Health care, } \\
\text { business services, entertainment and } \\
\text { recreation, education, legal, lodging, etc) }\end{array}$ \\
\hline Traded, Unskilled labor intensive & $\begin{array}{l}\text { Oil Refining } \\
\text { Mining } \\
\text { Tobacco } \\
\text { Leather } \\
\text { Primary Metals } \\
\text { Lumber } \\
\text { Textiles and Apparel } \\
\text { Stone } \\
\text { Furniture } \\
\text { Fabricated Metals } \\
\text { Agriculture } \\
\text { Paper } \\
\text { Food }\end{array}$ \\
\hline Traded, Skilled labor intensive & $\begin{array}{l}\text { Transportation Equipment } \\
\text { Rubber } \\
\text { Chemicals } \\
\text { Industrial Machinery } \\
\text { Instruments } \\
\text { Electronic Equipment } \\
\text { Printing and Publishing } \\
\text { Miscellaneous Manufactures }\end{array}$ \\
\hline
\end{tabular}

Notes to Table 1: Disaggregate sectors are classified as unskilled labor intensive if the share of total (direct and indirect) cost accounted for by less than college educated labor was less than the economy wide average in 1977. Manufactures, mining, and agriculture are classified as traded; all other sectors are classified as non-traded. 
Table 2 - Growth, 1970-1990

\begin{tabular}{|lrrr|}
\hline & $1970-80$ & $1980-90$ & $1970-90$ \\
\hline Growth in real wages and relative wages & & & \\
\hline HS dropouts & -0.08 & -0.15 & -0.22 \\
\hline HS graduates & -0.06 & -0.04 & -0.10 \\
\hline College graduates & -0.09 & 0.06 & -0.04 \\
\hline HS graduates/HS dropouts & 0.01 & 0.13 & 0.15 \\
\hline College Graduates/HS graduates & -0.03 & 0.10 & 0.06 \\
\hline College Graduates/HS dropouts & -0.02 & 0.24 & 0.22 \\
\hline Growth in factor supplies & & & \\
\hline HS dropouts & -0.20 & -0.12 & -0.30 \\
\hline HS graduates & 0.47 & 0.30 & 0.91 \\
\hline College graduates & 0.79 & 0.58 & 1.83 \\
\hline Capital & 0.45 & 0.30 & 0.88 \\
\hline Growth in prices & & \\
\hline Personal consumption deflator & 0.99 & 0.61 & 2.21 \\
\hline Non-traded, unskilled & 1.08 & 0.42 & 1.95 \\
\hline Non-traded, skilled & 0.90 & 1.02 & 2.83 \\
\hline Traded, unskilled & 1.90 & 0.04 & 2.02 \\
\hline Traded, skilled & 1.07 & 0.15 & 1.38 \\
\hline Growth in Total Factor Productivity & & & \\
\hline Non-traded, unskilled & 0.01 & 0.07 & 0.08 \\
\hline Non-traded, skilled & 0.05 & -0.09 & -0.05 \\
\hline Traded, unskilled & -0.04 & 0.13 & 0.08 \\
\hline Traded, skilled & 0.00 & 0.13 & 0.14 \\
\hline & & &
\end{tabular}

Notes to Table 2: The numbers in this table are the cumulative growth in each variable over the time period. Real wages are defined as nominal wages deflated by the personal consumption deflator from the National Accounts. 
Table 3 - Relative Price Changes by Decade

\begin{tabular}{|c|c|c|c|c|c|c|c|c|c|}
\hline & \multicolumn{3}{|c|}{ Price change $1960-70$} & \multicolumn{3}{|c|}{ Price change $1970-80$} & \multicolumn{3}{|c|}{ Price change $1980-90$} \\
\hline & $\begin{array}{l}\text { Share } \\
1960 \\
\end{array}$ & $\begin{array}{l}\text { Value } \\
\text { Added }\end{array}$ & $\begin{array}{c}\text { Gross } \\
\text { Output }\end{array}$ & $\begin{array}{c}\text { Share } \\
1970 \\
\end{array}$ & $\begin{array}{l}\text { Value } \\
\text { Added }\end{array}$ & $\begin{array}{c}\text { Gross } \\
\text { Output }\end{array}$ & $\begin{array}{c}\text { Share } \\
1980 \\
\end{array}$ & $\begin{array}{c}\text { Value } \\
\text { Added }\end{array}$ & $\begin{array}{c}\text { Gross } \\
\text { Output }\end{array}$ \\
\hline \multicolumn{10}{|c|}{ Non-traded, Unskilled labor intensive } \\
\hline Construction & 0.078 & 0.294 & 0.111 & 0.076 & 0.099 & 0.063 & 0.067 & 0.063 & 0.007 \\
\hline Transport & 0.049 & -0.022 & -0.014 & 0.044 & -0.172 & -0.066 & 0.042 & 0.000 & -0.029 \\
\hline Commun. & 0.026 & -0.051 & -0.030 & 0.028 & -0.401 & -0.329 & 0.032 & 0.150 & 0.148 \\
\hline Utilities & 0.024 & -0.212 & -0.150 & 0.028 & 0.270 & 0.597 & 0.030 & 0.443 & 0.012 \\
\hline Trade & 0.193 & -0.019 & -0.005 & 0.173 & -0.076 & -0.065 & 0.156 & -0.138 & -0.058 \\
\hline \multicolumn{10}{|c|}{ Non-traded, Skilled labor intensive } \\
\hline FIRE & 0.114 & 0.077 & 0.074 & 0.119 & -0.172 & -0.147 & 0.141 & 0.377 & 0.311 \\
\hline Oth.Services & 0.150 & 0.169 & 0.118 & 0.178 & -0.140 & -0.114 & 0.244 & 0.472 & 0.334 \\
\hline Govt & 0.017 & 0.353 & 0.204 & 0.016 & -0.028 & 0.012 & 0.017 & & 0.022 \\
\hline \multicolumn{10}{|c|}{ Traded, Unskilled labor intensive } \\
\hline Agriculture & 0.039 & 0.052 & 0.017 & 0.034 & -0.094 & -0.012 & 0.025 & -0.339 & -0.223 \\
\hline Mining & 0.023 & -0.132 & -0.069 & 0.047 & 2.680 & 1.211 & 0.021 & -0.452 & -0.288 \\
\hline Lumber & 0.009 & -0.076 & -0.046 & 0.007 & 0.056 & 0.058 & 0.006 & -0.105 & -0.093 \\
\hline Furniture & 0.005 & 0.048 & -0.004 & 0.004 & -0.312 & -0.145 & 0.004 & 0.076 & 0.017 \\
\hline Stone & 0.010 & -0.080 & -0.061 & 0.008 & & 0.049 & 0.006 & -0.176 & -0.089 \\
\hline PrimMetals & 0.022 & 0.017 & 0.010 & 0.014 & 0.031 & 0.099 & 0.010 & -0.094 & -0.096 \\
\hline FabMetals & 0.018 & -0.038 & -0.019 & 0.015 & -0.014 & 0.031 & 0.012 & -0.023 & -0.047 \\
\hline Food & 0.027 & -0.037 & -0.014 & 0.023 & -0.204 & -0.040 & 0.021 & -0.028 & -0.109 \\
\hline Tobacco & 0.002 & 0.030 & -0.002 & 0.002 & 0.099 & 0.053 & 0.003 & 3.134 & 1.063 \\
\hline Textiles & 0.007 & -0.250 & -0.136 & 0.005 & -0.530 & -0.236 & 0.004 & -0.221 & -0.107 \\
\hline Apparel & 0.010 & 0.007 & -0.055 & 0.008 & -0.433 & -0.272 & 0.006 & -0.118 & -0.075 \\
\hline Paper & 0.012 & -0.159 & -0.110 & 0.010 & -0.020 & 0.025 & 0.011 & 0.094 & 0.022 \\
\hline Oil Refining & 0.003 & -0.671 & -0.190 & 0.009 & 7.411 & 1.836 & 0.005 & -0.932 & -0.417 \\
\hline Leather & 0.003 & 0.070 & 0.002 & 0.002 & 0.059 & 0.011 & 0.001 & 0.041 & 0.004 \\
\hline \multicolumn{10}{|c|}{ Traded, Skilled labor intensive } \\
\hline Ind Mach & 0.032 & 0.166 & 0.077 & 0.030 & -0.162 & -0.086 & 0.024 & -0.491 & -0.291 \\
\hline Electronics & 0.024 & -0.254 & -0.154 & 0.021 & -0.387 & -0.219 & 0.019 & -0.255 & -0.139 \\
\hline TransEquip & 0.036 & -0.005 & -0.007 & 0.035 & 0.151 & 0.027 & 0.026 & -0.152 & -0.067 \\
\hline Instruments & 0.012 & -0.122 & -0.086 & 0.014 & -0.373 & -0.246 & 0.014 & -0.031 & -0.023 \\
\hline MiscManu & 0.005 & -0.152 & -0.086 & 0.004 & -0.046 & 0.025 & 0.004 & -0.193 & -0.123 \\
\hline PrintPub & 0.016 & 0.164 & 0.072 & 0.015 & -0.124 & -0.081 & 0.016 & 0.259 & 0.150 \\
\hline Chemicals & 0.021 & -0.307 & -0.181 & 0.021 & 0.187 & 0.143 & 0.021 & -0.080 & -0.049 \\
\hline Rubber & 0.012 & -0.318 & -0.210 & 0.012 & -0.088 & 0.004 & 0.011 & -0.165 & -0.093 \\
\hline
\end{tabular}

Notes to Table 3: This table reports sectoral proportional relative price changes, grouped by the aggregates defined in Table 1. For each decade, the first column lists the sector's share of GDP at the start of the decade, and the next two columns give the change in the value added and gross output prices relative to overall GDP. 
Table 4 - Correlations between Factor Shares and Explanatory Variables, 1963-1991

\begin{tabular}{|c|c|c|c|c|c|c|c|c|}
\hline & \multicolumn{2}{|c|}{ HS dropouts } & \multicolumn{2}{|c|}{ HS Graduates } & \multicolumn{2}{|c|}{ College Grads } & \multicolumn{2}{|c|}{ Capital } \\
\hline & raw & detrend & raw & detrend & raw & detrend & raw & detrend \\
\hline \multicolumn{9}{|c|}{ Prices, relative to Non-traded unskilled } \\
\hline Non-traded, skilled & -0.52 & 0.90 & 0.05 & -0.84 & 0.58 & -0.26 & 0.04 & 0.68 \\
\hline Traded, unskilled & -0.12 & -0.75 & 0.46 & 0.69 & 0.03 & 0.05 & -0.39 & -0.48 \\
\hline Traded, skilled & 0.89 & -0.35 & -0.64 & 0.21 & -0.90 & 0.02 & 0.53 & -0.09 \\
\hline \multicolumn{9}{|c|}{ TFP, relative to Non-traded unskilled } \\
\hline Non-traded, skilled & 0.56 & -0.87 & -0.05 & 0.90 & -0.62 & 0.19 & -0.04 & -0.73 \\
\hline Traded, unskilled & 0.25 & 0.81 & -0.62 & -0.80 & -0.16 & -0.07 & 0.55 & 0.58 \\
\hline Traded, skilled & -0.36 & 0.62 & -0.04 & -0.65 & 0.39 & -0.32 & 0.17 & 0.62 \\
\hline \multicolumn{9}{|c|}{ Labor supply, relative to capital } \\
\hline HS dropouts & 0.99 & 0.87 & -0.82 & -0.68 & -0.99 & -0.47 & 0.67 & 0.60 \\
\hline HS graduates & 0.46 & 0.39 & -0.45 & -0.23 & -0.50 & -0.72 & 0.55 & 0.41 \\
\hline College Graduates & -0.96 & -0.06 & 0.73 & -0.07 & 0.97 & 0.58 & -0.63 & -0.15 \\
\hline \multicolumn{9}{|l|}{ trend } \\
\hline time & -0.99 & & 0.77 & & 0.99 & & -0.62 & \\
\hline
\end{tabular}

Notes to Table 4: The numbers in this table are the simple correlation coefficients between the variables listed as rows (log relative prices, log relative TFP, log relative factor supplies, and time) and the factor shares listed as columns. For each factor share, the raw correlation as well as the correlation between the de-trended variables is reported. De-trended variables are the residuals from a regression on a constant and time. 
Table 5 - Estimated Factor Share equations, 1963-1991

\begin{tabular}{|lccc|}
\hline \multicolumn{4}{|c}{ Dependent variable: share of type of labor in national income } \\
& HS dropouts & HS Graduates & College Grads \\
\hline Factor Supplies & & & \\
\hline HS dropouts & 0.053 & -0.012 & -0.031 \\
& 2.39 & -0.28 & -3.39 \\
\hline HS graduates & -0.012 & 0.069 & -0.209 \\
& -0.28 & 0.49 & -10.13 \\
\hline College graduates & -0.031 & -0.209 & 0.084 \\
& -3.39 & -10.13 & 12.57 \\
\hline Capital & -0.011 & 0.152 & 0.155 \\
& -0.30 & 1.15 & 8.22 \\
\hline Prices, Total Factor Productivity & & -0.007 \\
\hline Non-traded, unskilled & -0.049 & 0.170 & -0.63 \\
& -2.35 & 4.10 & 0.034 \\
& 0.052 & -0.220 & 2.80 \\
\hline Non-traded, skilled & 2.22 & -4.05 & -0.002 \\
& -0.004 & 0.027 & -0.32 \\
\hline Traded, unskilled & -0.29 & 0.76 & -0.025 \\
& 0.000 & 0.023 & -1.95 \\
\hline Traded, skilled & 0.03 & 0.32 & \\
& & & \\
\hline
\end{tabular}

Notes to Table 5: This table reports the results of joint estimation of equation (5) for the shares of three different types of labor in national income as a function of prices, TFP, factor supplies, and time. The explanatory variables are listed as rows. T-statistics are in italics below each parameter estimate. Homogeneity, symmetry, and equality of price and TFP effects are all imposed. See equation (5) in the text for discussion of the specification. All explanatory variables enter logarithmically. 
Table 6 -Wage Elasticities, 1980

\begin{tabular}{|lccc|}
\hline & HS dropouts & HS graduates & College Grads \\
\hline Factor Supplies & & & \\
\hline HS dropouts & -0.387 & 0.076 & -0.038 \\
& -1.82 & 0.74 & -0.90 \\
\hline HS graduates & 0.305 & -0.414 & -0.556 \\
& 0.74 & -1.24 & -5.76 \\
\hline College graduates & -0.078 & -0.282 & -0.391 \\
& -0.90 & -5.76 & -12.44 \\
\hline Capital & 0.159 & 0.620 & 0.985 \\
& 0.48 & 1.99 & 11.16 \\
\hline Prices, Total Factor Productivity & & 0.310 \\
\hline Non-traded, unskilled & -0.119 & 0.746 & 5.94 \\
\hline Non-traded, skilled & -0.61 & 7.60 & 0.473 \\
& 0.804 & -0.208 & 8.34 \\
\hline Traded, unskilled & 3.64 & -1.61 & 0.179 \\
& 0.154 & 0.252 & 5.96 \\
\hline Traded, skilled & 1.31 & 2.97 & 0.038 \\
& 0.161 & 0.209 & 0.63 \\
\hline
\end{tabular}

Notes to Table 6: The elasticities reported in this table are derived from the estimated parameters reported in Table 1 combined with the actual factor and output shares of GDP for 1980. Formulas are given by equations (2), (3), (4), and (5) in the text. T-statistics are in italics beneath each elasticity. 
Table 7 - Sources of Wage Changes, 1970-1990

\begin{tabular}{|l|c|c|c|c|c|c|}
\hline & \multicolumn{3}{|c|}{ Wage Levels } & \multicolumn{3}{c|}{ Relative Wages } \\
\cline { 2 - 7 } & $\begin{array}{c}\text { HS } \\
\text { dropouts }\end{array}$ & $\begin{array}{c}\text { HS } \\
\text { grads }\end{array}$ & $\begin{array}{c}\text { College } \\
\text { grads }\end{array}$ & $\begin{array}{c}\text { HSgrad/ } \\
\text { dropouts }\end{array}$ & $\begin{array}{c}\text { college/ } \\
\text { HS grad }\end{array}$ & $\begin{array}{c}\text { college/ } \\
\text { dropouts }\end{array}$ \\
\hline Wage changes due to changes in Factor Supplies \\
\hline HS dropouts & 0.11 & -0.02 & 0.01 & -0.12 & 0.03 & -0.09 \\
\hline HS graduates & 0.28 & -0.38 & -0.50 & -0.51 & -0.21 & -0.61 \\
\hline College graduates & -0.14 & -0.51 & -0.71 & -0.43 & -0.41 & -0.67 \\
\hline Capital & 0.14 & 0.54 & 0.86 & 0.35 & 0.21 & 0.64 \\
\hline Subtotal & 0.39 & -0.54 & -0.73 & -0.67 & -0.42 & -0.81 \\
\hline Nominal wage changes due to changes in Prices & & & & \\
\hline Non-traded, unskilled & -0.23 & 1.45 & 0.60 & 2.19 & -0.35 & 1.09 \\
\hline Non-traded, skilled & 2.27 & -0.59 & 1.34 & -0.87 & 4.67 & -0.29 \\
\hline Traded, unskilled & 0.31 & 0.51 & 0.36 & 0.15 & -0.10 & 0.04 \\
\hline Traded, skilled & 0.22 & 0.29 & 0.05 & 0.05 & -0.18 & -0.14 \\
\hline Subtotal - nominal & 3.03 & 0.97 & 4.37 & -0.51 & 1.73 & 0.33 \\
\hline Subtotal - real & 0.26 & -0.39 & 0.67 & -0.51 & 1.73 & 0.33 \\
\hline Wage changes due to changes in total factor productivity & & & \\
\hline Non-traded, unskilled & -0.01 & 0.06 & 0.02 & 0.07 & -0.03 & 0.03 \\
\hline Non-traded, skilled & -0.04 & 0.01 & -0.03 & 0.06 & -0.04 & 0.02 \\
\hline Traded, unskilled & 0.01 & 0.02 & 0.01 & 0.01 & -0.01 & 0.00 \\
\hline Traded, skilled & 0.02 & 0.03 & 0.01 & 0.01 & -0.02 & -0.02 \\
\hline Subtotal & -0.02 & 0.12 & 0.02 & 0.14 & -0.09 & 0.04 \\
\hline Summary - Changes in real wages & \multicolumn{7}{c}{} & \\
\hline Total Explained & 0.72 & -0.69 & -0.55 & -0.82 & 0.44 & -0.74 \\
\hline Total Actual & -0.22 & -0.10 & -0.04 & 0.15 & 0.06 & 0.22 \\
\hline
\end{tabular}

Notes to Table 7: The numbers in this Table are derived by multiplying the elasticities reported in Table 4 by the cumulative growth numbers reported in the last column of Table 2. For example, the upper left hand number is equal to (the elasticity of the HS dropout wage with respect to the quantity of HS dropouts) $\times$ (growth in HS dropouts from 1970 to 1990) $=$ (growth in the HS dropout wage attributed to growth in HS dropouts), or $(-0.387) \times(-0.30)=0.11$. For numbers under the heading Wage changes due to changes in Prices, the first subtotal is the cumulated effect of the previous four rows; the second subtotal adjusts nominal wage growth for inflation. 
Table 8 -Reduced Form Wage Elasticities, 1980

\begin{tabular}{|c|c|c|c|}
\hline & HS Dropout wage & HS Graduate wage & College Grad wage \\
\hline \multicolumn{4}{|l|}{ Factor Supplies } \\
\hline HS dropouts & $\begin{array}{l}0.24 \\
1.19\end{array}$ & $\begin{array}{l}0.11 \\
0.96\end{array}$ & $\begin{array}{l}0.02 \\
0.22\end{array}$ \\
\hline HS graduates & $\begin{array}{r}-1.13 \\
-2.15 \\
\end{array}$ & $\begin{array}{r}-0.78 \\
-2.72 \\
\end{array}$ & $\begin{array}{r}-0.69 \\
-3.39 \\
\end{array}$ \\
\hline College graduates & $\begin{array}{l}0.09 \\
0.84\end{array}$ & $\begin{array}{l}0.04 \\
0.75\end{array}$ & $\begin{array}{l}-0.37 \\
-9.45\end{array}$ \\
\hline Capital & $\begin{array}{l}1.50 \\
1.82\end{array}$ & $\begin{array}{l}1.27 \\
2.83\end{array}$ & $\begin{array}{l}1.84 \\
5.78\end{array}$ \\
\hline \multicolumn{4}{|c|}{ Lagged Total Factor Productivity } \\
\hline Non-traded, unskilled & $\begin{array}{r}-0.34 \\
-0.39 \\
\end{array}$ & $\begin{array}{r}-0.04 \\
-0.08 \\
\end{array}$ & $\begin{array}{r}-0.51 \\
-1.55 \\
\end{array}$ \\
\hline Non-traded, skilled & $\begin{array}{r}-0.59 \\
-0.89\end{array}$ & $\begin{array}{l}-0.08 \\
-0.23\end{array}$ & $\begin{array}{l}0.00 \\
0.01\end{array}$ \\
\hline Traded, unskilled & $\begin{array}{l}0.21 \\
0.46 \\
\end{array}$ & $\begin{array}{l}-0.00 \\
-0.00 \\
\end{array}$ & $\begin{array}{l}0.31 \\
1.78\end{array}$ \\
\hline Traded, skilled & $\begin{array}{l}0.31 \\
0.76 \\
\end{array}$ & $\begin{array}{l}0.19 \\
0.85 \\
\end{array}$ & $\begin{array}{l}0.20 \\
1.28 \\
\end{array}$ \\
\hline \multicolumn{4}{|c|}{ International Instruments } \\
\hline Labor $\times$ Open, Poor & $\begin{array}{l}-0.10 \\
-1.11\end{array}$ & $\begin{array}{l}0.03 \\
0.56\end{array}$ & $\begin{array}{l}-0.09 \\
-2.66\end{array}$ \\
\hline Labor $\times$ Open, Low $Y$ & $\begin{array}{r}-0.06 \\
-2.66 \\
\end{array}$ & $\begin{array}{r}-0.04 \\
-3.29 \\
\end{array}$ & $\begin{array}{l}-0.03 \\
-3.53\end{array}$ \\
\hline Labor $\times$ Open, Med Y & $\begin{array}{r}-0.03 \\
-0.83 \\
\end{array}$ & $\begin{array}{l}-0.05 \\
-2.24 \\
\end{array}$ & $\begin{array}{r}-0.01 \\
-0.55 \\
\end{array}$ \\
\hline Labor $\times$ Open, Rich & $\begin{array}{l}0.02 \\
0.75 \\
\end{array}$ & $\begin{array}{r}-0.01 \\
-0.66 \\
\end{array}$ & $\begin{array}{r}-0.01 \\
-1.43 \\
\end{array}$ \\
\hline \multicolumn{4}{|c|}{ Other Domestic Instruments } \\
\hline Govt Purchases/GDP & $\begin{array}{r}-0.64 \\
-2.69 \\
\end{array}$ & $\begin{array}{l}-0.22 \\
-1.72 \\
\end{array}$ & $\begin{array}{r}-0.05 \\
-0.50 \\
\end{array}$ \\
\hline Age Structure 1 & $\begin{array}{l}2.59 \\
1.30\end{array}$ & $\begin{array}{l}3.53 \\
3.26\end{array}$ & $\begin{array}{l}-0.30 \\
-0.39\end{array}$ \\
\hline Age Structure 2 & $\begin{array}{l}-0.14 \\
-0.97\end{array}$ & $\begin{array}{r}-0.25 \\
-3.24 \\
\end{array}$ & $\begin{array}{l}0.07 \\
1.31\end{array}$ \\
\hline
\end{tabular}

Notes to Table 8: The elasticities reported in this table are derived from the estimated parameters of the reduced form regressions given by equation (7) combined with the actual factor and output shares of GDP for 1980. T-statistics are in italics beneath each elasticity. Formulas are given by equations (8)-(10) in the text. 


\section{Appendix 1 - Construction of Labor Data}

Data on wages were gathered from the March Annual Demographic file of the Current Population Survey (CPS), 1964-1992. The CPS provides, amongst other variables, information on labor force participation, age, education, industry of employment, and both total income and income components. The data on income and employment refer to the preceding year, hence our series refers to the years 1963-1991.

The sample includes the weekly wage and salary earnings of all non-selfemployed workers who were between the ages of 16 and 65 and worked at least one hour for pay in the previous year. We omitted self-employed workers because they tend to misrepresent their true income and may also have negative earnings. Wage and salary data were chosen because it contains a good measure of earned income by industry and education. Ideally, an hourly measure would be the best measure of relative labor supply or total effort for each educational group. However, neither hourly wages nor number of hours worked is asked consistently in this data set and an imputed hourly wage would not be reliable ${ }^{19}$.

We settled for weekly wages as opposed to annual wages because the relative number of total workers by group (picked up by annual numbers) can vary from the relative number of total weeks worked (picked up by weekly numbers). The weekly numbers address our concern for total work effort better and, as a result, were applied. The method used for computing weekly wages is described below.

\footnotetext{
19 The data asks you how many hours you worked last week which can be very different from the number of hours you worked the previous year. The latter is more important since we must match it with the previous year's income data.
} 
From 1964-1975 actual weeks worked are not recorded. However, a categorical variable is provided which tells us whether the earner worked $0,1-13$, 14-26, 27-39, 40-47, 48-49, or 50-52 weeks in the previous year. Actual weeks worked for the years $1976-1988^{20}$, were used to fit values for the missing data by regressing each categorical variable for weeks on 755 cells which controlled for race, sex, education (as defined below), census region, and experience ${ }^{21}$.

Each coefficient from these equations was then regressed on a weighted time trend, where the weight was equal to the number of observations, to see if weeks worked by cell could be predicted based upon a linear trend. For those that were significant at the $10 \%$ level a number of weeks worked value was fit. For those that were not significant, a weighted average was used to estimate the number of weeks worked with a given weeks category. Here, each cell mean was weighted by the number of observations for a given cell in year $t$ divided by the total number of observations for a given cell over the entire time period 1976$1988 .^{22}$

Next, a weekly wage was computed by dividing the annual wage and salary income by the number of weeks worked for each observation. Finally, a mean wage for each educational group, as defined below, was computed as a weighted average of each cell within that educational group. More explicitly, the mean

\footnotetext{
${ }^{20}$ The data from 1964-1988 are contained in a uniform data file. The years 1989-1992 were not used for this fitting procedure to omit any changes in survey method or data adjustment that might have occurred in these later survey years.

${ }^{21}$ The procedure used to compute experience is the same one described in Murphy and Welch (1992).

${ }^{22}$ A more detailed description of this imputation process is available from the authors upon request.
} 
wage $^{23}$ of each cell in the high school dropout group, for example, was weighted by the number of weeks that cell worked in a given year $t$ relative to the total number of weeks worked by all HS dropouts in year $t$. It is this weighted mean that is used in the analysis.

Before proceeding, it should be noted that the CPS top-codes annual wage and salary incomes above a certain level. Prior to computing the average weekly wage, we corrected for this censoring by adopting the method employed by Katz and Murphy (1992). That is, we multiplied each top-coded value by 1.45 .

We divided workers into three educational groups: did not complete high school (0-11 years of education); completed high school and some college (12-15 years of education); and college graduates (16+ years of education $)^{24}$. Individuals were assigned to a grade based upon their completion of that grade with one exception being those who did not complete the thirteenth grade. These individuals were grouped with the $13^{\text {th }}$ grade versus the $12^{\text {th }}$ because according to Park (1996), it is better to treat these individuals as having some college education rather than associating them with those who only have a high school diploma.

Total wage and salary employment was obtained from the Bureau of Labor Statistics from which the share of total employment for each skill was computed. Figures 1 through 4 illustrate some salient features of the wage and employment data.

\footnotetext{
${ }^{23}$ It should be noted that there are many observations within each cell. The mean wage of the cell is weighted by the March supplemental weight.

${ }^{24}$ This is the same breakdown used by Baldwin and Cain (1997).
} 